\title{
Model methods for the analysis of mesocosm experimental studies
}

\author{
A. G. Brinkman ${ }^{1}$, C. J. M. Philippart ${ }^{1,3}$ \& A. F. Zuur ${ }^{2}$ \\ ${ }^{1}$ DLO-Institute for Forestry and Nature Research (IBN-DLO); PO Box 167, \\ 1790 AD Den Burg, Texel, The Netherlands \\ ${ }^{2}$ University of Groningen, Faculty of Mathematics; PO Box 800, 9700 AV Groningen, \\ The Netherlands \\ ${ }^{3}$ Netherlands Institute for Sea Research; PO Box 59, 1790 AB Den Burg, Texel, \\ The Netherlands * \\ ABSTRACT: The response of experimental ecosystem dynamics to varying nutrient loads was \\ studied by analysing oxygen time-series. Time-series had been continuously recorded, and the data \\ were analysed on a daily basis using a computer model which describes basic oxygen processes. The \\ resulting sets of production and consumption parameters described the dynamic characteristics of \\ each basin during the experimental period of 180 days. Dynamical analysis appeared to be possible; \\ although the results did not indicate a clear relationship between oxygen dynamics and nutrient \\ supply in these systems.
}

\section{INTRODUCTION}

There are many tools and methods available to study ecosystems and ecosystem processes. They vary from large-scale ecosystem studies in the field to studies on a single species in the laboratory. Mesocosms are considered to be the link between these two extremes. Such medium-scaled experimental enclosures integrate many processes, but may still be controlled to a certain extent. The results resemble reality more than laboratory experiments do, due to the more natural behaviour of organisms (Brock et al., 1993).

Mesocosms, or model ecosystems, often are applied to study the system's reaction to a variety of input conditions such as nutrient load, temperature, insolation, or even pesticides. The natural system behaviour in mesocosms, or the system's reaction to varying input conditions is generally studied by monitoring chemical and biological state variables, such as phosphorus concentration, algal cell numbers and benthic filter feeder biomass or numbers (Bratbak et al., 1993; Carlsson \& Granéli, 1993; Doering et al., 1989; Hansen \& Blackburn, 1991; Hinga, 1992; Vanni \& Findlay, 1990; Widbom \& Elmgren, 1988). These results may be analysed using (multiple) regression analysis techniques and non-deterministic models such as time-related polynomes (Roberts, 1992). However, these methods generally stress the state of the system, rather than the dynamic interrelations. Other methods quantify processes in such systems, such as primary production rates, sediment/water fluxes of inorganic compounds and zooplankton community filtering rates (Niederlehner \& Cairns, 1990, Keller et al., 1990; Kelly et al., 1985; Nilsson et al.,

\footnotetext{
* Present address
} 
1991; Oviatt et al., 1986; Sampou \& Uviatt, 1991; Sullivan et al., 1991). Such processes are generally directly measured. The application of dynamic model analysis may also be considered: dynamic characteristics of the system are found by fitting dynamic model results to experimental data such as state variables and/or process rates. Most promising so far is the analysis of oxygen time series that leads to a quantification of oxygen production and consumption in the system (Van Straten, 1986; Van Straten \& Kouwenhoven, 1991; Keesman, 1989; Kouwenhoven, 1994). Oxygen is used because concentrations can automatically be assessed, resulting in hundreds of data per system per day.

\section{MATERIAL AND METHODS}

Outdoor marine mesocosms were constructed on the island of Texel in order to study shallow estuarine ecosystems, such as the Wadden Sea. These eight experimental basins were used in 1992 to examine the system's responses to changes in environmental conditions regarding nutrient loads (Benthic Eutrophication STudies: BEST), with special emphasis on the hypertrophic situation in the Venice Lagoon in Italy. The mesocosms were installed to closely resemble a relatively unpolluted situation in the Venice Lagoon. During this experiment, several biotic and abiotic state variables and processes were regularly measured, at least once every 5 weeks, in all mesocosms. In addition, oxygen concentrations, insolation and temperature were frequently measured, viz. every 30 seconds.

This paper concentrates on the oxygen data analysis. The objective is to derive daily parameters from these time-series in order to characterize the dynamic behaviour of each system during the research period. This implies that the available biotic data remained unused in this stage of the analysis.

Basic processes included in the oxygen model were production and consumption of oxygen and oxygen exchange between atmosphere and water. In complex ecosystem models, the description of both of the first processes may become very complicated, considering different kinds of primary producers and consumers. Here, it was assumed that the chemical and biotic system characteristics did not change during each daily analysis. This is a very crucial assumption, implying that each single analysis should be restricted to such a relatively short period. The length of this period cannot be shorter than one day, because the complete 24 -hour oxygen concentration cycle is to be analysed to cover both production and consumption. If the period were somewhat longer, the assumption of constant biotic concentration would become less realistic. The experiment lasted 180 days. Thus, for each of the eight systems, 180 daily parameter sets became available that supplied information on the system dynamics in terms of oxygen production and consumption. These parameters vary during the season and are expected to be different for each basin. They contain information on the underlying biotic variables, and should, therefore, reflect the different reaction of each basin to the experimental treatment.

\section{Mesocosm setup}

Eight $21-\mathrm{m}^{2}$ basins with $0.55 \mathrm{~m}$ water depth and $0.0 \mathrm{~m}$ sedument were set up identically, the only difference being the additional nitrogen and phosphorus input of each system (Fig. ${ }^{1}$ ). The basins were continuously flushed with Wadden Sea water. The 

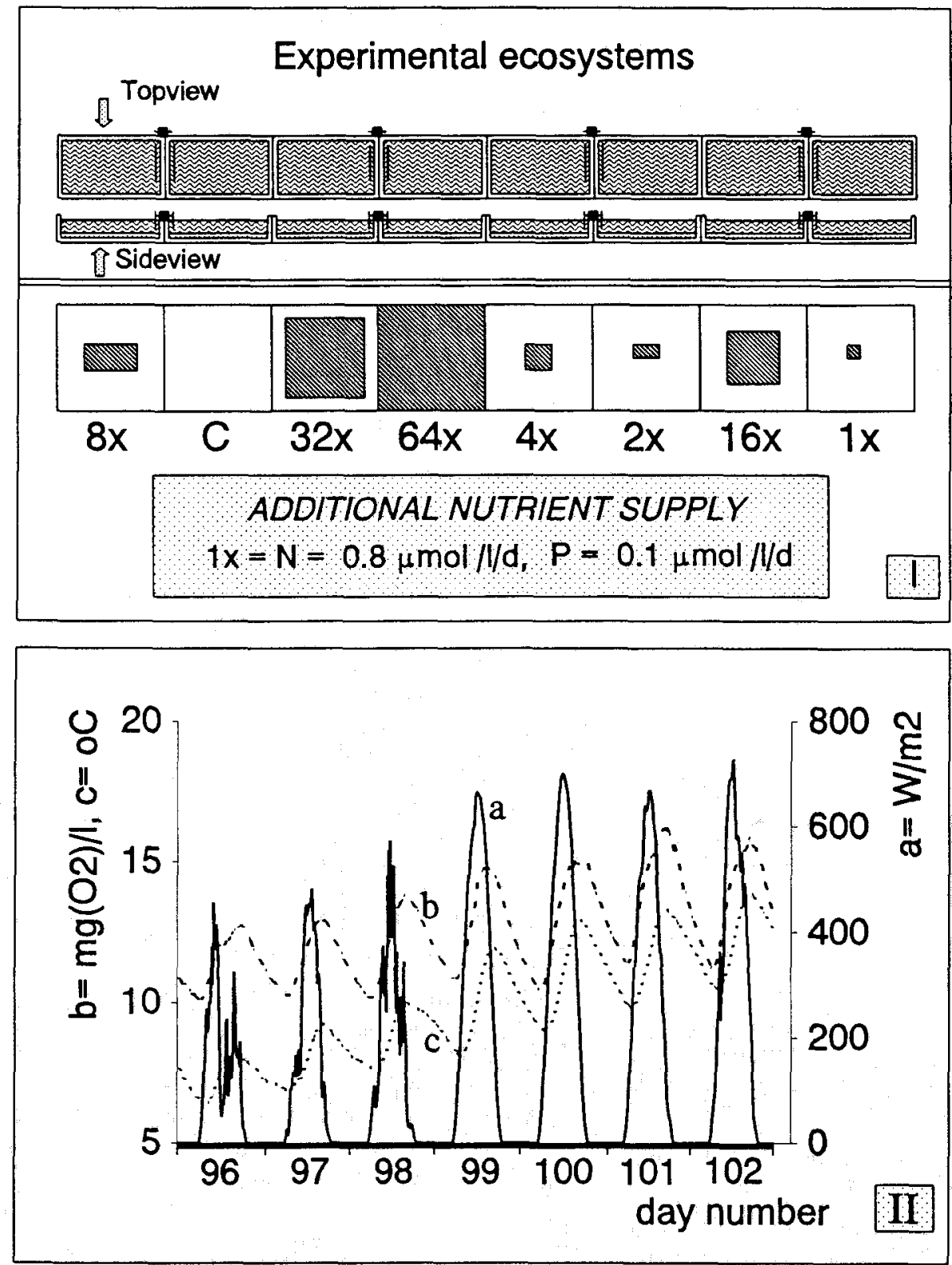

Fig. 1. I: Experimental setup: experimental basins, with position of wave boards and addition of nutrients to each basin; II: data for days $96-102$ in $1992 ; a=$ solar insolation $\left(\mathrm{W} \cdot \mathrm{m}^{-2}\right) ; \mathrm{b}=$ oxygen concentration $\left(\mathrm{mg} \mathrm{O} \mathrm{O}_{2} \cdot 1^{-1}\right), \mathrm{c}=$ water temperature $\left({ }^{\circ} \mathrm{C}\right)$

residence time of the water in a basin was 6.5 days. The response of the mesocosm ecosystems to the different nutrient additions was monitored from March to September 1992. Oxygen concentration (WTW OXI219 + Trioxmatix 600/130 oxygen probe), insola- 
tion (Licor LC-Li 200SB pyranometer) and water temperature were measured every 30 seconds, and 15-minute averages were recorded (Fig. ${ }^{\mathrm{II}}$ ) on a 14-bit Campbell CR10-64k datalogger. Wind data at $10 \mathrm{~m}$ standard height was provided by the Royal Dutch Meteorological Institute (KNMI, 1992), recorded at the nearby weather station at "The Kooy" Airport (Den Helder). The basins are referred to as Mxx, where $\mathrm{xx}$ is the nutrient addition (M00, M01,..., M64).

\section{MODEL ANALYSIS}

\section{Basic oxygen model}

In the mesocosm study, the production of oxygen results from the assimilatory activities of macroalgae and pelagic and benthic microalgae. The intensity of the oxygen production is a function of a number of environmental conditions:

$$
\text { Production }=\mathrm{f}(\text { light, temperature, nutrients, algae }, \ldots)
$$

The assumption that the nutrient concentrations and algae densities had not changed during each day, implied that light and temperature had been the only important factors. For the model, it was also assumed that $F$ (temperature) $=1$ :

$$
\text { Production }=\mu_{\max } \cdot F(\text { light })
$$

the factor $\mu_{\max }$ combined all the other variables excluding light. The production-light relationship was kept as simple as possible and started with a somewhat rough approximation:

$$
\text { Production }=\mathrm{q} \cdot \mathrm{I}_{0} \quad\left(\mathrm{mg} \mathrm{O} \mathrm{O}_{2} \cdot \mathrm{1}^{-1} \cdot \mathrm{d}^{-1}\right)
$$

where $\mathrm{I}_{0}$ was the global radiation $\left(\mathrm{W} \cdot \mathrm{m}^{-2}\right)$. Thus, $\mathrm{q}\left(\mathrm{mg} \mathrm{O} \mathrm{O}_{2} \cdot \mathrm{l}^{-1} \cdot\right.$ day $\left.^{-1} \cdot\left(\mathrm{W} \cdot \mathrm{m}^{-2}\right)^{-1}\right)$ contained all the other relationships.

Consumers include benthic and pelagic bacteria that degrade organic matter (detritus), and respiring algae and benthic and pelagic animals.

$$
\text { Consumption }=\mathrm{f}(\text { temperature, } \text { mineralization, } \ldots)
$$

Consumption includes all the respiratory activities and all the bacterial mineralization processes. The first depends on the activity and contents of algae and fauna species; the second is determined by the content and composition of the detritus. Oxygen consumption takes place in the water and in the sediment. Although temperature is a key variable here, it was assumed that $F$ (temperature $)=1$ :

$$
\text { Consumption }=\mathrm{R} \quad\left(\mathrm{mg} \mathrm{O} \mathrm{O}_{2} \cdot \mathrm{l}^{-1} \cdot \mathrm{d}^{-1}\right)
$$

$R$ being the sum of all consumption processes.

Exchange of oxygen across the atmosphere/water interface is the physical key process that controls the oxygen content in the water:

$$
\text { Reaeration }=\mathrm{k}_{r} \cdot\left(\mathrm{C}_{\infty}(\mathrm{sal}, \mathrm{T})-\mathrm{C}(\mathrm{t})\right) \quad\left(\mathrm{mg} \mathrm{O}, \mathrm{l}^{-1} \cdot \mathrm{day}^{-1}\right)
$$

where $k_{r}$ was the reaeration coefficient $\left(\right.$ day $\left.^{-1}\right)$ and $C_{\infty}\left(s_{a l}, T\right)$ the oxygen saturation concentration in the water. The temperature $(\mathrm{T})$ and salinity (sal) dependencies of $\mathrm{C}_{\infty}$ 
were taken into account (see e.g. APHA, 1985). $\mathrm{k}_{\mathrm{r}}$, itself is also temperature-dependent, but the variation with temperature is much smaller than that of $\mathrm{C}_{\kappa_{\alpha}}$.

Thus, the model reads

$$
\frac{\mathrm{dC}(\mathrm{t})}{\mathrm{dt}}=\mathrm{q} \cdot \mathrm{I}_{0}(\mathrm{t})-\mathrm{R}+\mathrm{k}_{\mathrm{r}} \cdot\left(\mathrm{C}_{\infty}(\mathrm{sal}, \mathrm{T})-\mathrm{C}(\mathrm{t})\right) \quad\left(\mathrm{mg} \mathrm{O}_{2} \cdot \mathrm{I}^{-1} \cdot \mathrm{day}^{-1}\right)
$$

Input/output processes were not included in this analysis, since the time constant for these processes was about 1 week, which was much larger than that of the processes mentioned here: $O(\tau)=1$ day.

\section{Data analysis}

The parameters $q, R$ and $k_{r}$ had to be estimated from the oxygen time-series (Figure $1^{\text {II). }}$. Two methods were applied:

(1) differential equation (7) was numerically solved, and the computed oxygen concentrations were compared with the data $\left(\mathrm{C}_{\mathrm{m}}\right)$. Usually, $\mathrm{C}(\mathrm{t}=0)$ was also estimated, since it cannot be assumed that $\mathrm{C}(\mathrm{t}=0)$ is exactly known. For this method, the STEM software package was applied (ReMeDy, 1991), using a Nelder-Mead (simplex) minimization procedure which is robust although not very time efficient (Kouwenhoven, 1994).

(2) differential equation (7) was solved from data-point to data-point following

$$
\frac{\Delta \mathrm{C}}{\Delta \mathrm{t}}=\mathrm{q} \cdot \mathrm{I}_{\mathrm{O}}(\mathrm{t})-\mathrm{R}+\mathrm{k}_{\mathrm{r}} \cdot\left(\mathrm{C}_{\infty}\left(\mathrm{sal}_{1} \mathrm{~T}\right)-\mathrm{C}(\mathrm{t})\right)
$$

The analysis was started for each separate time interval $[t, t+\Delta t]$ with the measured situation at time $=t$. The difference between measured $\left(C_{m}\right)$ and computed oxygen concentrations was much smaller in this second approach, since the computed prediction was limited to one time-step, which is 15 minutes in the time series.

The conditions for both operations are that $\mathrm{C}(\mathrm{t})$ and $\mathrm{I}_{0}(\mathrm{t})$ are continuous and can be differentiated at $[t, t+\Delta t]$. Purely mathematically, this was not the case, because global radiation and $\mathrm{C}(\mathrm{t})$ were measured at discrete time intervals. However, biologically the influence is not discrete but is always some average of the present and the preceding conditions. Hence, it was assumed that equation (7) was mathematically valid for the biological system. From equation (8), it follows that

$$
\mathrm{C}(\mathrm{t}+1)=(1-\Delta \mathrm{t}) \cdot \mathrm{C}(\mathrm{t})+\Delta \mathrm{t} \cdot \mathrm{I}_{0}(\mathrm{t})+\Delta \mathrm{t} \cdot \mathrm{k}_{\mathrm{r}} \cdot \mathrm{C}_{\infty}(\mathrm{sal}, \mathrm{T})-\Delta \mathrm{t} \cdot \mathrm{R}
$$

had to be computed. The MATLAB scientific software (MATLAB, 1991) was used to solve equation (9).

In both cases, minimizing $\mathrm{S}$, with

$$
\mathrm{S}=\sum_{\mathrm{t}=1}^{\mathrm{m}} \mathrm{R}_{\mathrm{t}}^{2}=\sum_{\mathrm{t}=1}^{\mathrm{m}}(\hat{\mathrm{C}}(\mathrm{t})-\mathrm{C}(\mathrm{m}, \mathrm{t}))^{2}
$$

regarding the wanted parameters ( $q, R$ and $k_{r}$ ) yields best parameter values. $C(m, t)$ is the measured value at time $t . \hat{C}(t)$ is the computed oxygen concentration at each time $t$.

\section{Uncertainties}

When applying a model, one has to be sure that the model is adequate, and that the data are sufficient to discriminate between the mentioned processes. 


\section{Data}

The available oxygen time series $\mathrm{C}(\mathrm{m}, \mathrm{t})$ were not exact. Two error sources are relevant: the instrumental error and the experimental error.

\section{Model}

The model is not complete; some errors remain. The true model reads

$$
\frac{\mathrm{dC}(\mathrm{t})}{\mathrm{dt}}=\mathrm{q} \cdot \mathrm{I}_{0}(\mathrm{t})-\mathrm{R}+\mathrm{k}_{\mathrm{r}} \cdot\left(\mathrm{C}_{\infty}(\mathrm{t})-\mathrm{C}(\mathrm{t})\right)+\mathrm{v}(\mathrm{t})
$$

where $v(t)$ is stochastic. $v(t)$ is thought to be normally distributed, having an expected mean value of $v(t)=0$. The study of the residues supplies information on $v(t)$; the model may be assumed to be correct when $\mathrm{v}(\mathrm{t})$ has a white noise characteristic. If not, the residues may contain additional information. Equation (10) minimizes $v(t)$.

\section{Parameters}

A model may be correct, but the collected data may not be sufficient to discriminate between all the described processes. Therefore, correlations between parameters have to be studied. This was done by computing.

$$
\mathrm{S}(\Theta)=\mathrm{S}(\hat{\Theta}) \cdot\left[1+\frac{\mathrm{p}}{\mathrm{n}-\mathrm{p}} \cdot \mathrm{F}(\mathrm{p}, \mathrm{n}-\mathrm{p}, 1-\alpha)\right]
$$

where $\hat{\Theta}$ was the parameter set minimizing $S$ (equation 10), and $\Theta$ was the parameter set for which $S$ obeys equation (13), for p parameters, $n$ datapoints and a $100 \cdot(1-\alpha) \%$ confidence contour; $F$ being the relevant Fisher's distribution value. The application of equation (13) caused a problem: the 96 observed oxygen concentrations per day were not independent. Thus, the value of $n$ in equation (13) was much less than 96 when analysing the results of one day. There is not much literature available on estimating the uncertainty of time-series parameters. As a rough and optimistic estimate, it was assumed that a maximum of six parameters could be derived from the oxygen data. Thus, $n=6$ and $p=3$ in this analysis. The resulting contours were exact; the confidence value assigned to such a contour is approximate when the model is not strictly linear in all its parameters (Draper \& Smith, 1981; Jansen et al., 1990). In this case, the estimated value for $n$ (number of independent data-points) introduced a large extra uncertainty regarding the 'real' confidence value. Such contours show how well one can discriminate between the separate parameters by using the data that are collected. If necessary, the model may be adapted (without or by hardly changing the numbers of parameters), resulting in better discrimination properties.

\section{Some model adaptations}

\section{Data uncertainties}

Instrumental errors were tested by recording the output every 30 seconds. Short-term variations were found to exist at the level of the instrument's accuracy, about $2^{-14}$ times the maximum recorded value, so at the $\mu \mathrm{g} \mathrm{O}_{2} \mathrm{l}^{-1}$ level. They were neglected in this research. 
Experimental errors were tested by investigating the mixing characteristics in one of the basins. It was found that the mixing was sufficient to prevent local differences. It was concluded that the measurements represent the actual situation in all basins.

\section{Model uncertainties}

The model residues ( $v(t)$ in equation 12) contained some daily periodicity. Production seemed to be relatively larger during the morning than during the afternoon, or: oxygen consumption seems to be relatively larger during the afternoon. It is rather hard to discriminate between these two possibilities. A better result was obtained by the incorporation of a light limitation function:

$$
\mathrm{F}(I)=\left(\begin{array}{c}
\frac{I}{I_{\mathrm{k}}}: I<I_{\mathrm{k}} \\
1.0: I \geq I_{\mathrm{k}}
\end{array}\right) \quad(-)
$$

where $I_{k}\left(W \cdot m^{-2}\right)$ is the photosynthetic parameter. A value of $I_{k}=400\left(W \cdot m^{-2}\right)$ was found to be appropriate. The production term (equation 3 ) now reads

$$
\text { Production }=\mathrm{q}^{0} \cdot \mathrm{F}(I) \quad\left(\mathrm{mg} \mathrm{O} \mathrm{O}_{2} \cdot \mathrm{l}^{-1} \cdot \mathrm{d}^{-1}\right)
$$

where $\mathrm{q}^{0}$ is the maximum productivity (when $\mathrm{F}(\mathrm{I})=1.0$ ). To compare q from equation (3) to $\mathrm{q}^{0}$, one should read

$$
\mathrm{q}=\mathrm{q}^{0} \cdot \frac{\overline{\mathrm{F}(I)}}{\bar{I}} \quad\left(\mathrm{mg} \mathrm{O}_{2} \cdot \mathrm{l}^{-1} \cdot \mathrm{d}^{-1} \cdot\left(\mathrm{W} \cdot \mathrm{m}^{-2}\right)^{-1}\right)
$$

where $\mathrm{F}(\mathrm{I})$ and $\mathrm{I}$ are averaged over the 24 -hour period.

\section{Parameter uncertainties}

Results for basin M08 are shown in Figure $2^{1}$ for day 100. The STEM package was used, the model is represented by equation (7). It was first checked how the parameters were correlated. The combined approximately $90 \%$ confidence contours for the three possible combinations are shown in Figure $2^{\mathrm{II}}$. Although the individual confidence interval may be rather small, combinations of parameters allow a much larger deviation from the best estimates.

It turned out that during times of production (the oxygen concentration was generally above the saturation value, similar to the situation shown in Figure $2^{\mathrm{I}}$ ), the $\mathrm{k}_{\mathrm{r}}$ and the $\mathrm{R}$ parameter could hardly be separated, while during times of consumption (usually later in the year, when oxygen concentrations were generally below the saturation value) $k_{r}$ and q were hard to separate.

Since the $k_{r}$-parameter depends mainly on wind speed, it was decided to use an empirical wind- $k_{\mathrm{r}}$ relationship to compute all $\mathrm{k}_{\mathrm{r}}$-values, instead of estimating them. In Figure 3, all estimated $k_{r}$-values are related to the measured wind speed UWI $\left(\mathrm{m}^{-1}\right)$ at $10 \mathrm{~m}$ standard height (KNMI, 1992):

$$
\mathrm{k}_{\mathrm{r}}=\operatorname{depth}^{-1} \cdot[0.517+0.129 \cdot \mathrm{UWI}] \quad\left(\mathrm{d}^{-1}\right)
$$

The constant term $(0.517)$ in equation (17) was caused by the mechanical wave board 

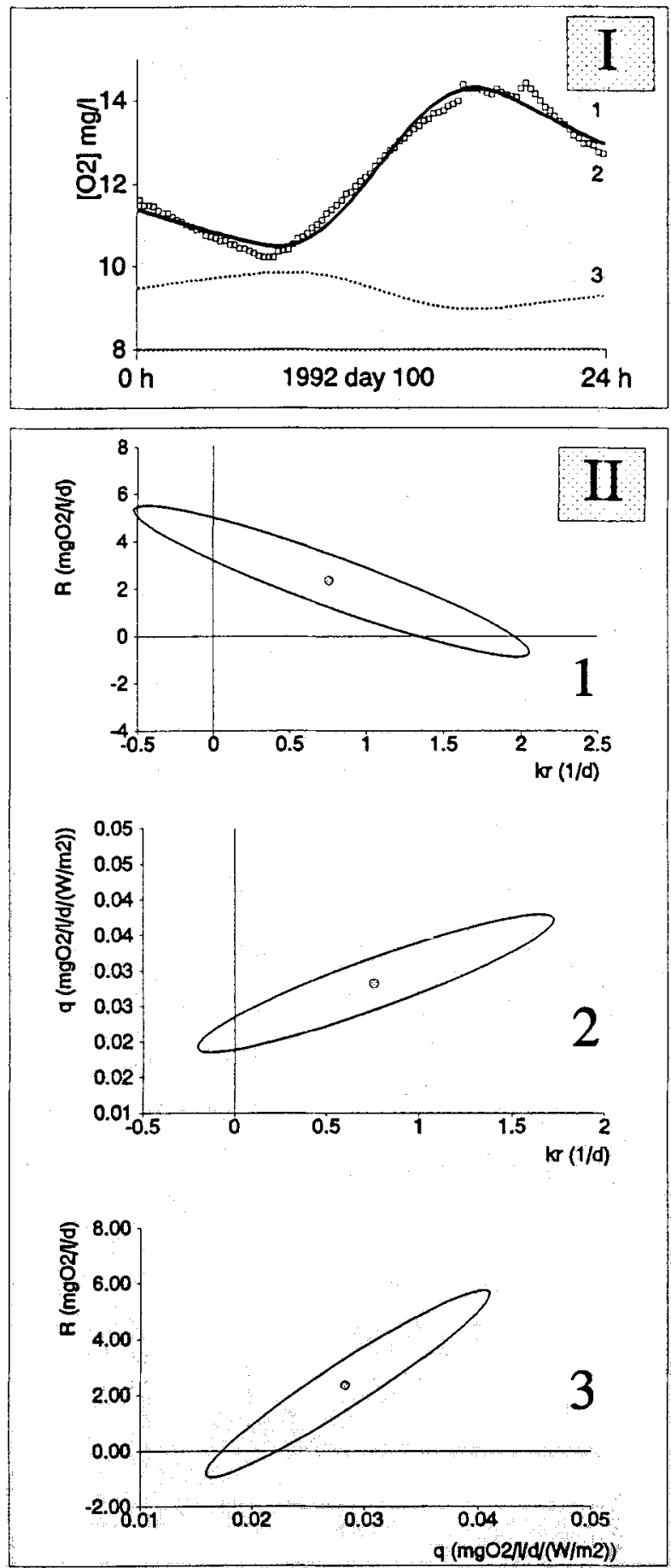
mixing in the basin. The $k_{r}$-values as shown in Figure 3 were not very different from the values resulting from Banks' review (Banks, 1975); only the sharp increase at higher UWI-values was not observed here. The scatter of $\mathrm{k}_{\mathrm{r}}$-values illustrates the variability in computation results. It was decided to compute $\mathrm{k}_{\mathrm{r}}$ according to this empirical relationship: the rest of the analysis was done using equation (17). The result was that unrealistic values for $\mathrm{k}_{\mathrm{r}}$ were avoided; at the same time, the resulting $\mathrm{q}$ - and $\mathrm{R}$-values obtained more biological meaning.

\section{RESULTS}

In Figure $4, \mathrm{q}^{0}$ (maximum productivity) and $\mathrm{R}$ values are shown for basin $\mathrm{M} 08$ in 1992. It is obvious that neither the maximum productivity, nor the system's oxygen consumption show a smooth pattern during the experimental period. The occasionally rather abrupt changes indicate that the computation of $\mathrm{q}^{0}$ and $\mathrm{R}$ probably was not completely stable, although $\mathrm{k}_{\mathrm{r}}$-values were computed now, instead of estimated. Results by Kouwenhoven (1994) show a similar non-smooth behaviour. At the start of the experiment, R-values for basin M08 even reached negative values. Obviously, $\mathrm{q}^{0} \cdot \mathrm{F}$ (I)

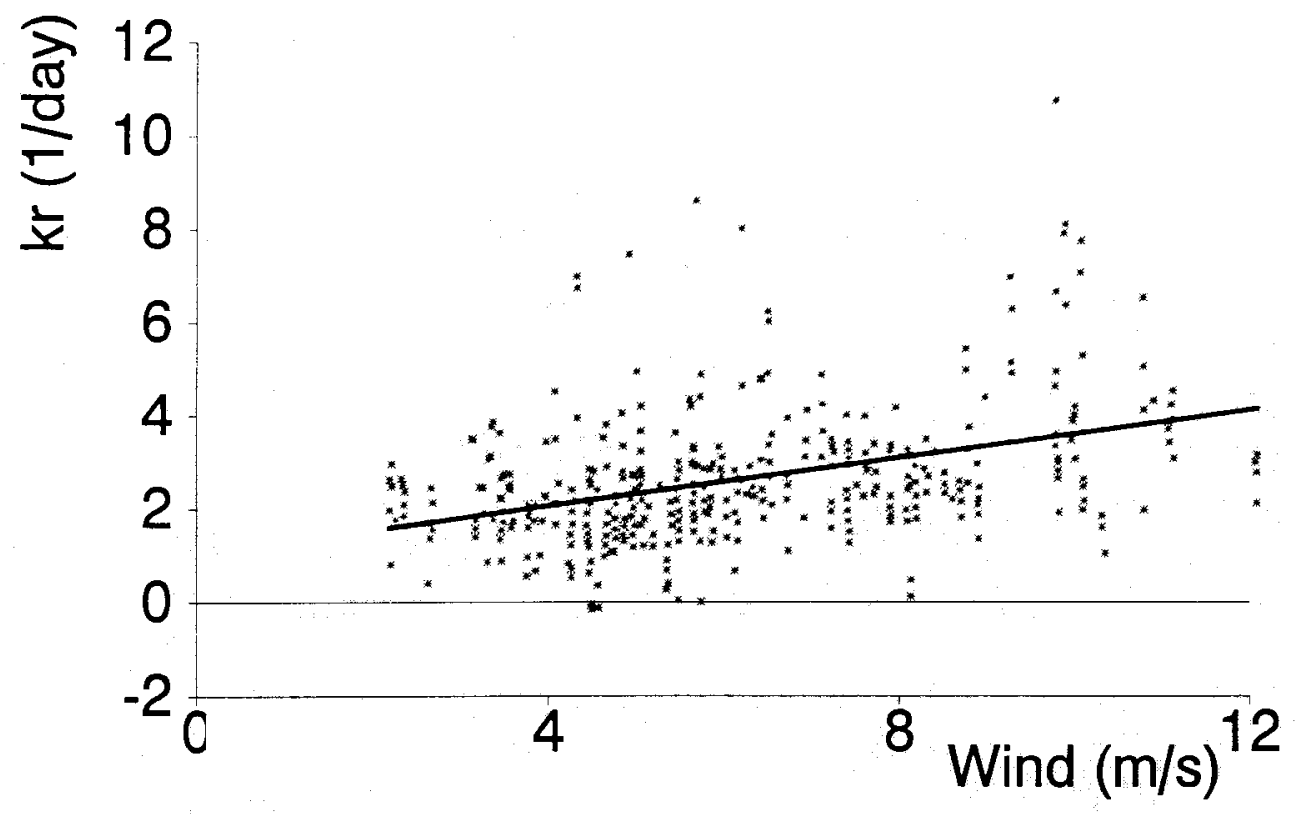

Fig. 3. Relationship between estimated (after equation 9) $\mathrm{k}_{\mathrm{r}}$-values and daily averaged wind speed (KNMI, 1992). Reqression line represents equation (17)

Fig. 2. I: Result of STEM-analysis for day $100 \mathrm{in} 1992$, basin $\mathrm{Mo8}$. $\mathbf{k}_{\mathbf{r}}=0.729 \mathrm{~d}^{-1}, \mathrm{R}=2.28$ $\left(\mathrm{mg} \mathrm{O} 2 \cdot \mathrm{l}^{-1} \cdot \mathrm{d}^{-1}\right), \mathrm{q}=0.0272\left(\mathrm{mg} \mathrm{O}_{2} \cdot \mathrm{l}^{-1} \cdot \mathrm{d}^{-1}\left(\mathrm{~W} \cdot \mathrm{m}^{-2}\right)^{-1}\right) \cdot 1$ (line): simulated oxygen concentration 2 (squares): measurements, 3 (dots): oxygen saturation values.

II: Approximately $90 \%$ parameter uncertainty contours for 6 datapoints and 3 parameters $(n=6$, $\mathrm{p}=3$ in equation 13) for day 100 STEM-results, basin $M 08,1, \mathrm{k}_{\mathrm{r}}$ and $\mathrm{R}, 2, \mathrm{k}_{\mathrm{r}}$ and $\mathrm{q}, 3: \mathrm{q}$ and $\mathrm{R}$ Estimates of $\mathrm{k}_{\mathrm{r}}, \mathrm{q}$ and $\mathrm{R}$ are given as dots 

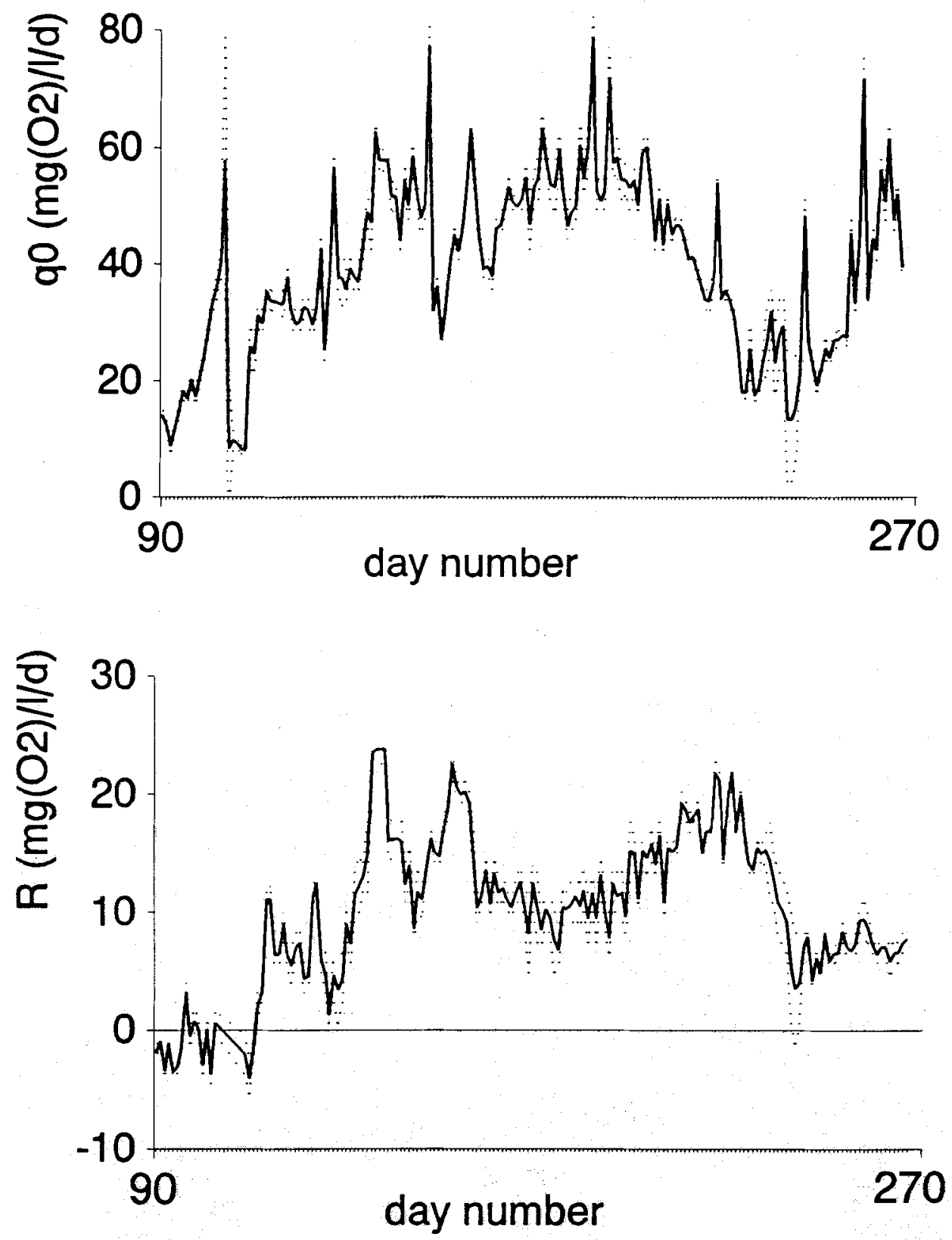

Fig. 4. Daily estimates (after equation 9 ) $\mathrm{q}^{0}$ and $\mathrm{R}$ for basin M08 during 1992, including an estimate of their individual $90 \%$ reliability (Holtrop, 1993) 


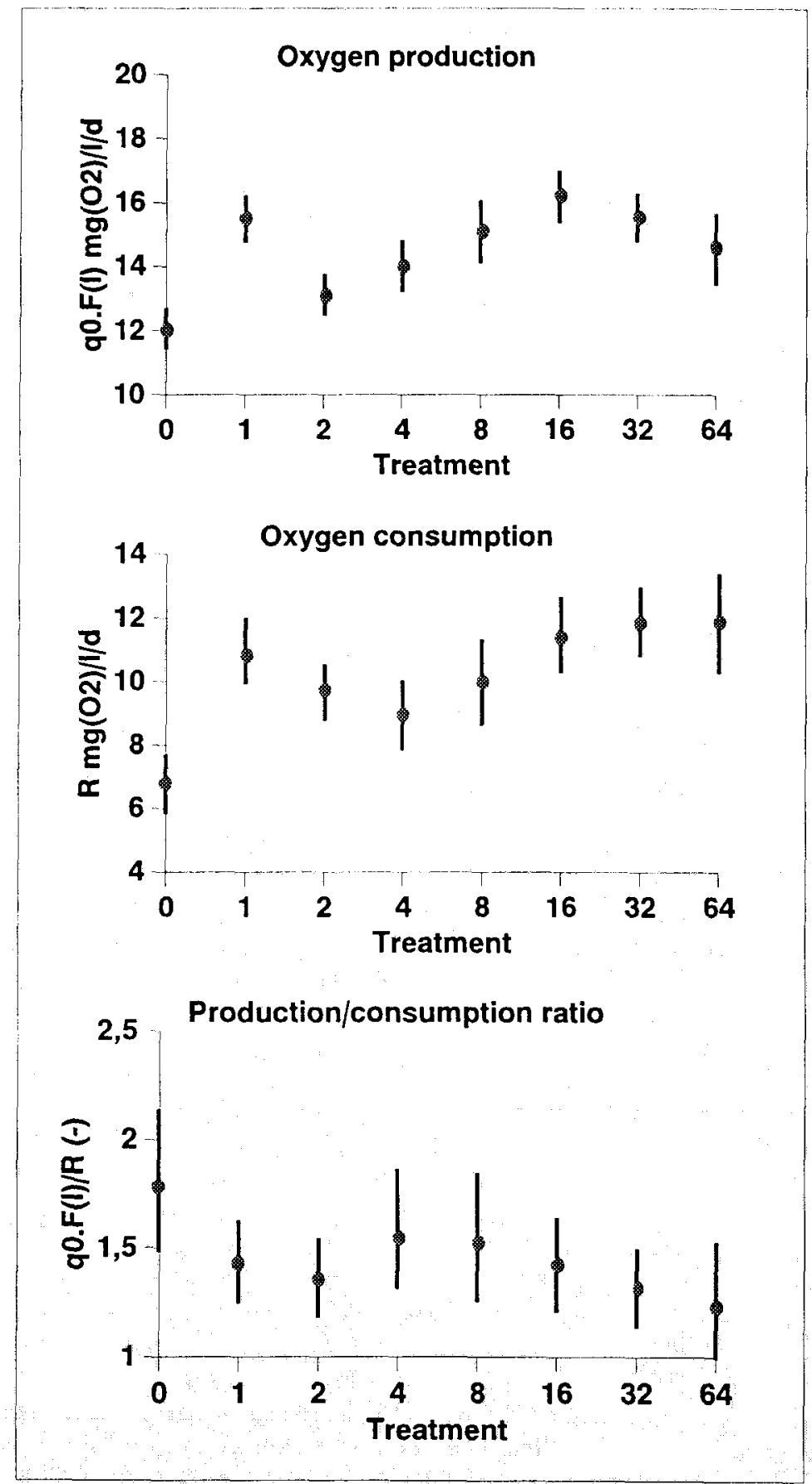

Fig. 5. Estimated production $\mathrm{q}^{0} \cdot \mathrm{F}$ (I) (equation 15), R-values (both in $\mathrm{mg} \mathrm{O}_{2} \cdot \mathrm{l}^{-1} \cdot \mathrm{d}^{-1}$ ) for all basins, and estimated production/consumption ratio $=q^{\circ} \cdot F(I) / R$ related to the treatment of each basin 
could not account for the oxygen production. Here the computed reaeration might be too high (negative contribution to $\mathrm{C}(\mathrm{t})$ ). However, the same analysis including estimated reaeration (not shown) also resulted in negative R-values.

Because of such irregularities, it was decided to average all the 180 daily production $\left(\mathrm{q}^{0} \cdot \mathrm{F}(\mathrm{I})\right.$ and consumption $(\mathrm{R})$ values. All these values are depicted in Figure 5, for each of the eight basins. The production/consumption ratios are also shown. Neither consumption nor production changed very much with increasing nutrient loads. The different nutrient loads are very weakly reflected by the dynamic responses of the experimental systems. The production/consumption ratio decreased somewhat with increasing loads, indicating that at higher loads consumption became more important. Kouwenhoven (1994) analysed several natural systems and found production/consumption ratios of roughly 1.0 .

\section{DISCUSSION}

The most important conclusion is that it generally seems possible to derive activity parameters for oxygen consumption and production from the dissolved oxygen timeseries. However, one should be very careful in assigning strict values to the results: parameter uncertainties should always be known. The parameter values show how the dynamics of the system change during the season, and how they differ from basin to basin, thus reflecting the effect of the treatment. As a result of such an analysis, system characteristics are derived that would otherwise not be available. Thus, the method as presented here extends the knowledge of the ecological system; it allows a better interpretation of other biotic and abiotic data.

The production-radiation relationship was kept very simple in our analysis. The introduction of a photosynthetic parameter through equation (14) gave better results in terms of a lower sum-of-squares, but the value of $I_{k}$ was not very well investigated; it is possible to make improvements. Equation (14) with $\mathrm{I}_{\mathrm{k}}=400\left(\mathrm{~W} \cdot \mathrm{m}^{-2}\right)$ implies that there is some photosynthetic saturation. However, a translation to biological parameters needs a description of the underwater light climate (see e.g. Golterman, 1975), which is beyond the scope of this paper.

For all basins, $\mathrm{q}^{0} \cdot \mathrm{F}(\mathrm{I}) \cdot \mathrm{R}^{-1}>1.0$ (Figure 5 ). This may be a result of

- the experiment mainly being carried out during the growing season (storage of organic matter); the period of mineralization is not completely covered.

- outflow of produced matter; observations indicated that such an outflow occurred. The biotic data that were sampled indicated that organic matter storage probably was of minor importance compared to flushing.

- a structural error in the computation of $\mathrm{k}_{\mathrm{r}}$. The oxygen concentrations were generally above the saturation level because the experiment was carried out during the growing season. This implies that reaeration was a loss term in the oxygen budget, similar to $R$. A structural error in $k_{r}$ would cause a structural error in $R$.

In this paper, data-analysis was restricted to the oxygen time-series. During the research, more biotic and abiotic variables were monitored. Since the $\mathrm{q}^{0}$ - and R-parameter values reflect the activities of the organisms, the linking of these parameter values with biotic and abiotic observations would increase the value of the present analysis, and vice versa. Brinkman et al. (1994) describe such an analysis to estimate the separate contribution of 
the three major groups of primary producers in the system. The result is quite hopeful, although it proved to be difficult to find a clear relationship between each contribution and the nutrient treatment.

The authors feel that further progress may be possible after the introduction of a more detailed description of biotic and abiotic processes. However, a problem would then be that not all the process descriptions can be separately calibrated. All the applied parameters were estimated in the present analysis. After the first complete analysis, we decided to compute the reaeration parameter, but the applied relationship was not known in advance. In an extended model, such a complete parameter estimation would not be possible anymore. This implies that a priori information has to be added to such extended models. Finally, integrated ecosystem models with many detailed descriptions of biotic and abiotic processes may also be applied to the mesocosm results (e.g. Brinkman et al., 1991). In that case, an important goal may not only be system analysis, but also the testing of the adequacy of such an ecosystem model. Model ecosystem results as described in the present paper have to be extrapolated to 'real' systems, for which ecosystem models and their more simple precursors may be, in our opinion, very useful. System analysis as presented here may enhance the applicability of ecosystem models and model ecosystems in understanding large systems.

Acknowledgements. The authors wish to thank J. Schoonheden who assisted the data acquisition, A. van Leeuwen (Netherlands Institute for Sea Research, NIOZ) who checked the text and J. van der Meer (NIOZ) for his contribution to the interpretation of parameter uncertainty results.

\section{LITERATURE CITED}

APHA (American Public Health Association), 1985. Standard methods for the examination of water and waste water. APHA, Washington, $874 \mathrm{pp}$.

Banks, R. B., 1975. Some features of wind action on shallow lakes. - J. environ. Eng. Div. ASCE 101, 813-827.

Bratbak, G., Egge, J. K. \& Heldal, M., 1993. Viral mortality of the marine algae Emiliania huxleyi (Haptophycea) and termination of algal blooms. - Mar. Ecol. Prog. Ser. 93, 39-48.

Brinkman, A. G., Raaphorst, W. van \& Ruardij, P., 1991. Objectives of the WASP-3 project and outline of the EcoWasp ecosystem model. - Institute for Forestry and Nature Research, DLO Report 91/35, 15 pp.

Brinkman, A. G., Philippart, C. J. M. \& Holtrop, G., 1994. Mesocosms and ecosystem modelling. Vie Milieu 44 (1), 29-37.

Brock, T., Crum, S., Leeuwangh, P., Lucassen, W. \& Wijngaarden, R. van, 1993. Modelecosystemen: brug naar het veld. - Landschap 10, 23-36.

Carlsson, P. \& Granéli, E., 1993. Availability of humic bound nitrogen for coastal phytoplankton. Estuar, coast. Shelf Sci. 36, 433-447.

Doering, P. H., Oviatt, C. A., Beatty, L. L., Banzon, V. F., Rice, R., Kelly, S. P., Sullivan, B. K. \& Fritshen, B. J., 1989. Structure and function in a model coastal ecosystem: silicon, the benthos and eutrophication. - Mar. Ecol. Prog. Ser. 52, 287-299.

Draper, N. \& Smith, H., 1981. Applied regression analysis. Wiley, New York, 709 pp.

Golterman, H. L., 1975. Physiological limnology. (Dev. Wat. Sci. 2). Elsevier, Amsterdam, 489 pp.

Hansen, L. S. \& Blackburn, T. H., 1991. Aerobic and anaerobic mineralization of organic material in marine sediment mesocosms, - Mar. Ecol. Prog. Ser. 75, 283-292.

Hinga, K. R, 1992. Co-occurrence of dinoflagellate blooms and high pH in marine enclosures. - Mar. Ecol. Prog. Ser. 86, 181-187.

Holtrop, G., 1993. Dynamical characteristics of a model ecosystem: impact of eutrophication. Thesis Univ. Groningen, 79 pp. 
Jansen, P. H. M., Slob, W. \& Rotmans, J., 1990. Gevoeligheidsanalyse en onzekerheidsanalyse: een inventarisatie van ideeën, methoden en technieken. RijksInstituut voor Volksgezondheid en Milieuhygiëne, Bilthoven, $118 \mathrm{pp}$.

Keesman, K., 1989. A set-membership approach to the identification and prediction of ill-defined systems: application to a water quality system. Thesis, Univ. Twente, Enschede, $134 \mathrm{pp}$.

Keller, A. A., Doering, P. H., Kelly, S. P. \& Sullivan, B. K., 1990. Growth of juvenile Atlantic menhaden, Brevoortia tyrannus (Pisces: Clupeidae) in MERL mesocosms: effects of eutrophication. - Limnol. Oceanogr. 35, 109-122.

Kelly, J, R., Berounsky, V. M., Nixon, S. W. \& Oviatt, C. A., 1985. Benthic-pelagic coupling and nutrient cycling across an experimental eutrophication gradient. - Mar. Ecol. Prog. Ser. 26, $207-219$.

KNMI (Ed.), 1992. Maandelijks overzicht der weersgesteldheid (Nr.89, April-October). KNMI, De Bilt, $56 \mathrm{pp}$.

Kouwenhoven, J. P. M., 1994. Procesmatige karakterisering van de zuurstofhuishouding ten behoeve van de normstelling. Thesis, Univ. Twente, $200 \mathrm{pp}$.

MATLAB, 1991. Version 3.5j. The MathWorks, Inc, Natick.

Niederlehner, B. R. \& Cairns, J., 1990. Effects of ammonia on periphytic communities. - Environ. Pollut. 66, 207-221.

Nilsson, P., Jönsson, B., Lindström Swanberg, I. \& Sundbäck, K, 1991. Response of a marine shallow-water sediment system to an increased load of inorganic nutrients. - Mar. Ecol. Prog. Ser. 71, 275-290.

Oviatt, C. A., Keller, A. A., Sampou, P. A. \& Beatty, L. L., 1986. Patterns of productivity during eutrophication: a mesocosm experiment. - Mar. Ecol. Prog. Ser. 28, 69-80.

ReMeDy (Ed.), 1991. STEM, Simulation Tool for Easy Modelling. Vs. 2.0 reference manual. ReMeDy, Enschede, $100 \mathrm{pp}$.

Roberts, E. A., 1992. Sequential data in biological experiments: an introduction to research workers. Chapman \& Hall, London, 240 pp.

Sampou, P. \& Oviatt, C. A., 1991. Seasonal patterns of sedimentary carbon and anaerobic respiration along a simulated eutrophication gradient. - Mar. Ecol. Prog. Ser. 72, 271-282.

Straten, G. van, 1986. Identification, uncertainty assessment and prediction in lake eutrophication. Thesis, Univ. Twente, Enschede, 240 pp.

Straten, G. van \& Kouwenhoven, J. P. M., 1991. Identification of a mechanistic model for diurnal dissolved oxygen patterns in lakes with discrete time series analysis. - Wat. Sci. Technol. 24, $17-23$.

Sullivan, B. K., Doering, P. H., Oviatt, C. A., Keller, A. A. \& Frithsen, J. B., 1991. Interactions with the benthos alter pelagic food web structure in coastal waters. - Can. J. Fish. aquat. Sci. $48(6)$, 2276-2284.

Vanni, M. J. \& Findlay, D. L., 1990. Trophic cascades and phytoplankton community structure. Ecology 71, 921-937.

Widbom, B. \& Elmgren, R., 1988. Response of benthic meiofauna to nutrient enrichment of experimental marine ecosystems. - Mar. Ecol. Prog. Ser. 42, 257-268. 